\title{
Indonesian to English Translation Strategies Used in Webtoon "My Pre-Wedding"
}

\author{
Lilik Istiqomah ${ }^{1}$, Darojatin Khasanah ${ }^{2}$, Aisyana Tauhida ${ }^{3}$, Ristina Ayu Ningtyas ${ }^{4}$, and Anisa Nur \\ Rohimah $^{5}$ \\ Institut Agama Islam Negeri (IAIN) Surakarta, Surakarta, Indonesia \\ mdcorp100@gmail.com
}

\begin{abstract}
ARTICLE HISTORY
Received : 3 May 2020

Revised : 9 May 2020

Accepted : 30 June 2020
\end{abstract}

\section{KEYWORDS}

Translation

Translation Strategies

Webtoon

Comic Platform

\begin{abstract}
This paper maps the Indonesian-English translation strategies within a comic published in Webtoon, arguably the most popular global digital comic service platform in this generation. The data was taken from Webtoon. The data is an Indonesian Webtoon entitled "My Pre-Wedding" created by Annisa Nisfihani and its translation into English by Pujangga Team. This study's design is qualitative, primarily describing the data by way of document review. Researchers catagorised the data into six translation strategies as stated by Baker Mona (1992). The researchers accumulated 261 data of translation strategies. Based on the analysis undertaken, the translation strategies used are mainly general word (17 findings $=6.5 \%)$, cultural substitution $(47$ findings $=18 \%)$, loan word $(16$ findings $=$ $6.1 \%$ ), paraphrase using a related word (53 findings $=20.3 \%$ ), paraphrase using unrelated words (63 findings $=24.1 \%$ ), and omission (65 findings $=24.9 \%$ ). The results not only contribute to the research on language translation strategies, but also give insight on how they apply within the new generation's smartphone cyberculture.
\end{abstract}

\section{Introduction}

Comic has been known as an entertaining medium that can be read by people at all age. According to Pradani (2017), comic is a type of art that arranges pictures in a combined story. Because of the combination of words and pictures, thus it will help the readers much better understanding the story itself. As further explanation, Riyanti \& Setianto (2018) stated that in comics, the text or the writing takes the role of a complement to the picture such as giving dialogue, narration and so be more precise. Thus, comic can be defined as a kind of art which contains texts and pictures arranged to tell a story, here the text functions as a complement of the pictures to support the story line.

At the former era, comic can only be enjoyed in the form of printed book, nowadays comic has developed into modern form. It facilitates the readers to access and read the comic everywhere and every time in their PC, smartphone or other gadgets. As the number of portable display platforms and the quality of digital display continues to increase so, too do the number of comics available digitally. This medium gave another term of comic which is called as digital comic. One of the most well-known digital comic applications used by Indonesians is Webtoon (Web Cartoon) which is originally from South Korea as a part of Line's social media products. Webtoon can be accessed by the readers in many languages, therefore there are some comics published in more than one country. In line with that fact, some comics in Webtoon are translated in other languages from the original one. Comic translations in
Webtoon have two forms, the official translation which is done by translation team of Line's cooperation and fan translation which are done by the comic fans.

Ekasani, Yadnya, Artawa, \& Indrawati (2018) stated that translation is the change of the source language (SL) into the target language (TL). In line with the statement above, Santika (2015) said that translation is the process of transferring a message from souce language into target language. In short, translation is a process in finding equivalent utterance from Source Language (SL) to Target Language (TL) without deviating from the actual context (Saleh \& Weda, 2018). Translation process requires appropriate strategies to convey the meaning and maintain the story line; therefore there is no misleading information between Source Language (SL) and Target Language (TL).

There are some previous researches that have been done. For example, the study about The Translation Strategy of Slang Expression in Comic Entitled The Punisher by Santika (2015). Also, Pradani (2017) discussed the translation analysis of humor in Webtoon "Si Juki: as a boarding house" by Faza Ibnu. And another study was done by Issy Yuliasri entitled "Translators' Censorship in English-Indonesian Translation of Donald Duck Comics" (2018). Based on previous studies above, none of them investigated the area of translation strategies used in Webtoon comic translation. Because of the limited studies in that area, the researchers conducted this study. Hence, the issue that would be discussed here is translation strategies used by translators in Webtoon comic translation. The aim of this study is to investigate what kind of 
translation strategies used in Webtoon comic entitled "My Pre-Wedding" and which are mostly used in that translation.

\section{Literature Review}

\subsection{Comic and Translation of Comic}

There is no consensus among comics scholars as to the definition of comics. Pradani (2017) stated that "Comic is a kind of art using pictures arranged in a combined story". In line with that, Riyanti \& Setianto (2018) stated that in comic, text or writing takes role as a complement to the picture such as giving dialogue, narration and so be more precise. As the definitions of comic differentiate one another, we can still conclude that comic itself is constructed by pictures and text arranged in sequence to tell readers a story.

Comic is one of entertaining media that is loved by everyone (Pradani, 2017). The translation in the comic field also becomes more familiar in which it can be beneficial for several parties including creator, translator and the reader. In line with comic translation, Zanettin (2015) said that the translation of comic is different from 'translation proper' not only because words co-exist with non-verbal systems, but also because verbal language in comics is only part -if sometimes the only part (i.e offered translation)- of what gets translated. From the statements mentioned above, in translating a comic, the translator does not only translate the verbal language which is in the form of the sentence or words but also non-verbal language in the form of visual images. This points are actually the same with rendering a film that is known by subtitling (Istiqomah, Erawati, \& Suparno, 2019). In subtitling, translator should not only translate the original intention of source text but also cultural information as well.

\subsection{Translation Strategies}

In translation process, translators should consider the various cultural differences between source text (ST) and target text (TT) that come during a translation process (Pelawi, 2016). Moreover, Alqaryouti \& Sadeq (2016) explained that the better translator should be aware of complexities of differences between cultures. Therefore, translators should choose appropriate strategies for making readers more understand with the context of the text. According to Mona (1992: 26-42) lists eight strategies of translation (Translation by a more general word, Translation by more neutral/ less expressive word, Translation by cultural substitution, Translation using a loan word or loan word plus explanation, Translation by paraphrase using a related word, Translation by paraphrase using unrelated words, Translation by omission, and Translation by illustration). While As-Safi in Arabiyat (2016) stated that there are two strategies of translation (The general strategies which deal different text types and specific strategies which tackle a certain text type, readership, and scope).
In this study, the researchers used six strategies of translation by Mona (1992). First, Translation by a more general word, this is one of most common strategies to deal with many types of nonequivalence, the example of this strategy is "the next ferry's in three days" which translated into "Kapal berikutnya tiga hari lagi". Second, Translation by cultural substitution, this strategy involves replacing a culture-specific item or expression with a target language item considering its impact on the target reader, the example of this strategy is "A little wine, a friedly chat" which translate into "Sedikit anggur, menggobrol ringan". Third, Translation using a loan word or loan word plus explanation, this strategy is usually used in dealing with culture-specific items, modern concepts, and buzz words, the example of this strategy is "your whisky's watered down!" which translated into "dia menguragi wiskimu!".. Fourth, Translation by paraphrase using a related word, this strategy is used when the source item in lexicalized in the target language but in a different form, and when the frequency with which a certain form is used in the source text is obviously higher that it would be natural in the target language, the example of this strategy is "He's got rhytm!" which translated into "Mari kita bernyanyi". Fifth, Translation by paraphrase using unrelated words, the paraphrase strategy can be used when the concept in the source item is not lexicalized in the target language, the example of this strategy is "Ah, my litlle pick-me-up, thank you, Mahalia" which translated into "Oh, obat energiku, terima kasih, Mahalia". And sixth, Translation by omission, this may be a drastic kind of strategy, but in fact it may be even useful to omit translating a word or expression in some contexts, the example of this strategy is "And my bridge is falling into the water" which translated into "Dan jembatanku roboh".

\section{Method}

"My Pre-wedding" is one of the most popular Indonesian webtoon with the score rating of 9,73 out of 10 and that has been translated into fourteen languages. The researchers took "My Pre-wedding" by Anisa Nisfihani as the data source of this research. It told about the obstacles of Adimas and Adelia's pre-wedding. To answer the research questions, descriptive qualitative research was done by the researcher. According to Cresswell (2012), qualitative research is descriptive in what the researcher is interested in process, meaning, and understanding gained through word or picture. The source language of data that was analyzed was Indonesia and the target language was English. By analyzing two texts, the frequency of each strategy of translation can be identified to determine the mostly used translation strategy in this Webtoon. The researchers analyze the utterances of Webtoon "My PreWedding". The method of data collection is documentation. The unit analysis of this research was all utterances in Webtoon "My Pre-wedding" with total 26 episodes. 
Table 1. Data Tabulation of My Pre-Wedding Webtoon

\begin{tabular}{|c|c|c|c|c|}
\hline No & $\begin{array}{c}\text { Translation } \\
\text { Strategy }\end{array}$ & Frequency & Percentage & Number of Data \\
\hline 1. & $\begin{array}{c}\text { Translation by a more } \\
\text { general word }\end{array}$ & 17 & $6.5 \%$ & $\begin{array}{c}179,186,187,196,201,227,232 \\
239,240,241,242,256,257,258 \\
259,260,261\end{array}$ \\
\hline 2. & $\begin{array}{l}\text { Translation by } \\
\text { cultural substitution }\end{array}$ & 47 & $18 \%$ & $\begin{array}{c}1,2,12,21,28,29,30,37,44,45 \\
50,54,55,56,57,58,59,66,67,74, \\
78,81,82,84,98,106,113,123 \\
124,130,131,139,145,147,154 \\
177,189,220,221,220,230,233 \\
236,244,250,253,255\end{array}$ \\
\hline 3. & $\begin{array}{l}\text { Translation using a } \\
\text { loan word or loan } \\
\text { word plus } \\
\text { explanation }\end{array}$ & 16 & $6,1 \%$ & $\begin{array}{c}3,4,13,16,17,24,25,26,33,108 \\
182,193,202,209,234,257\end{array}$ \\
\hline 4. & $\begin{array}{l}\text { Translation by } \\
\text { paraphrase using a } \\
\text { related word }\end{array}$ & 53 & $20.3 \%$ & $\begin{array}{c}7,11,14,15,31,43,44,49,53,56, \\
60,61,73,88,89,90,91,92,95,96, \\
97,100,101,111,116,117,118, \\
125,136,137,148,155,156,161 \\
164,165,168,173,174,183,184 \\
188,190,192,195,197,217,218 \\
219,224,226,228,245 .\end{array}$ \\
\hline 5. & $\begin{array}{l}\text { Translation by } \\
\text { paraphrase using } \\
\text { unrelated words }\end{array}$ & 63 & $24.1 \%$ & $\begin{array}{c}5.8,9,19,22,23,36,37,38,39,48, \\
51,52,62,63,64,70,71,77,99,107, \\
112,114,115,126,127,128,135, \\
141,142,146,150,151,157,160, \\
162,166,172,175,176,180,181, \\
185,191,194,198,203,205,208, \\
212,213,214,222,225,231,237, \\
238,246,249,251,252,254\end{array}$ \\
\hline 6. & $\begin{array}{l}\text { Translation by } \\
\text { omission }\end{array}$ & 65 & $24.9 \%$ & $\begin{array}{c}6,10,18,26,27,34,35,40,41,42, \\
46,47,65,68,69,72,75,76,80,83 \\
85,86,87,92,93,102,103,104 \\
105,108,109,110,119,120,121 \\
122,129,133,134,138,143,144 \\
149,152,153,158,159,163,167 \\
169,170,171,199,200,202,206 \\
207,210,211,215,216,223,235 \\
243,248\end{array}$ \\
\hline
\end{tabular}

\section{Results}

From Webtoon My Pre Wedding, the researchers found out there are 261 data which categorize into six strategies. The total of the data in each strategy is presented in the data tabulation displayed on Table 1. As displayed, translation by omission was the most often used by the translator (24, $9 \%$ ) because the translator might be faced any difficulties for translating some words and even though some words have been removed, the meaning and intention of the sentence still conveyed to the target readers. Then, the following most used strategy is translation by using unrelated words with the percentage number $24,1 \%$. Whereas, translation by was loan word or loan word plus explanation rarely used by the translator $(6,1 \%)$ because the translator might find difficulties to find the appropriate words to convey the meaning, so that the translator decided to maintain the original words of source language and some translations contains the explanation of words in target language.

\subsection{Translation by More General Words}

In this Webtoon, the researchers found 17 data $(6.5 \%)$ of translation by a more general word. Here are the examples and the explanation of the data which are translated by this strategy

\section{SL: Baru terasa pegelnya}

TL: I can feel the soreness

Data 179/MPW/2015 
The first example is "Baru terasa pegelnya!" which is translated to "I can feel the soreness". The real meaning of pegel is ache that usually happens to bond and hinge, thus the translator chose to translate pegel to soreness which means the ache that can happen in any part of body.

SL: Aku mau ke apotek sebentar ya, maag ku kayaknya kambuh!

TL: I need to go to the drugstore for a while, I think I got a stomachache!

\section{Data 186/MPW/2015}

The next example is "Aku mau ke apotek sebentar ya, maag ku kayaknya kambuh!" which is translated to "I need to go to the drugstore for a while, I think I got a stomachache". The real meaning of maag is one kind of stomachache that concern the inflammation of stomach layers, thus the translator chose stomachache that means ache which happens to stomach in general. Stomachache itself has many kinds of aches and maag is one of it

\subsection{Translation by Cultural Substitution}

In this Webtoon, the researchers found 47 data $(18 \%)$ of translation by cultural substitution. Here are the examples and the explanation of the data which are translated by this strategy

\section{SL: Pelet atau susuk gitu misalnya?}

\section{TL: Like witchcraft or black magic maybe?}

\section{Data 001/MPW/2015}

The example above is "Pelet atau susuk gitu misalnya?" which is translated to "Like witchcraft or black magic maybe?". In Indonesia pelet is the local Indonesian term of a magical manipulation to influence someone's subconscious in order to make him or her fall in love with the sender of that magic. Whereas, the term pelet is not familiar in other countries, therefore the translator chose the word witchcraft to replace it. Moreover, susuk is the local Indonesian term of magical manipulation for making someone looks more pretty or handsome. Similar to the reason of using pelet, translator used black magic to adjust the culture of the target language.

\section{SL: Mungkin nanti saat jujuran adek bisa minta apa yang adek mau. \\ TL: Well, for bridewealth* you can ask for anything. \\ *Bridewealth: in Indonesia it's still common for the groom to be's family to bring presents for bride to be's family close to the wedding day.}

\section{Data 037/MPW/2015}

The next example is "Mungkin nanti saat jujuran adek bisa minta apa yang adek mau" which is translated to "Well, for bridewealth you can ask for anything". Jujuran is the tradition of Banjar specifically located in one of cities in South Borneo which is the presents given to bride to be's family from groom to be's family. Basically, it can be money or things which are requested by bride to be. While, the translator chose the word bridewealth to imply jujuran in order to adjust the culture of the target language. Bridewealth itself means marriage payment from the husband to be and his kin to the bride's kin to officialize a marriage.

\subsection{Translation by Loan Words with/without Explanation}

In this Webtoon, the researchers found 16 data $(6.1 \%)$ of translation by using loan word or loan word plus explanation. Here are the examples and the explanation of the data which are translated by this strategy

\section{SL: Mas Adimas gak punya akun media sosial ya?}

TL: Mas Adimas doesn't have any social maedia accounts?

\section{Data 017/MPW/2015}

The first example is the sentence "Mas Adimas gak punya akun media sosial ya" which is translated to "Mas Adimas doesn't have any social maedia accounts". The translator maintain the word "Mas" and add the explanation of it below the panel, thus it shows that the translator used translation by loan word plus explanation to translate the word.

\section{SL: Nanti ku belikan martabak.}

TL: I'll buy you some martabak.

Data 193/MPW/2015

The next example is the sentence "Nanti ku belikan martabak" which translated to "I'll buy you some martabak". The translator still used the word martabak without adding a further explanation of it. Therefore, it shows that the translator used translation by loan word. Martabak itself means an omelette consists of vegetable slices and chopped meat or chicken. It is a dish which usually found in Saudi Arabia, Yemen, Indonesia, Malaysia, Singapore, and Brunei.

\subsection{Translation by Paraphrasing with Related Words}

In this Webtoon, the researchers found 53 data (20.3\%) of translation by paraphrase using related word. Here are the examples and the explanation of the data which are translated by this strategy.

\section{SL: Yuk! Entar keburu jumatan!}

\section{TL: come on! It's gonna be Friday prayer time!}

Data 236/MPW/2015

In the example mentioned above both the word "jum'atan" and "Friday prayer time" has the same sense, dictionary meaning, and also familiar in the source language and target language 


\section{SL: Jangan remehkan kekuatan gosip ibu-ibu! \\ TL: Never doubt the power of house wife gossip.}

\section{Data 073/MPW/2015}

In that example, both word "ibu-ibu" and "house wife" are related to each other. Those words have similar sense, dictionary meaning and familiar in souce and target language which shows that the translator used this strategy.

\subsection{Translation by Paraphrasing with Unrelated Words}

In this Webtoon, the researchers found 63 data $(24.1 \%)$ of translation by paraphrase using unrelated word. Here are the examples and the explanation of the data which are translated by this strategy:

\section{SL: Aku tidak maksud menggodamu.}

TL: I did't mean to bother you.

\section{Data 231/MPW/2015}

The first example is "Aku tidak maksud menggodamu." which translate into "I did't mean to bother you". The real meaning of "bother" is actually disturbing, but the context of the occurance is when Adelia's ex-boyfriend meets her unintentionally and try to tempt her. Thus, it made the meaning of "bother" and "menggoda" have similar intention although both of the words do not have related word and exact similar meaning.

\section{SL: Tapi ini benar-benar nggak seperti biasanya}

TL: but really, this is strange

\section{Data 205/MPW/201}

In the example mentioned here is "Tapi ini benar-benar nggak seperti biasanya" which is translated to "but really, this is strange". The phrase nggak seperti biasanya refers to something which does not happen as usual. The translator translated it to strange which also has the same meaning with the source language even though the translator used unrelated word. Thus, we can conclude that both word and phrase have an equivalent meaning, so the translator used this strategy.

\subsection{Translation by Omission}

In this Webtoon, the researchers found 65 data $(24.9 \%)$ of translation by omission. Here are the examples and the explanation of the data which are translated by this strategy.

\section{SL: Kata Pak Lurah rapatnya dimajukan.}

TL: The meeting time has been moved forward.

\section{Data 072/MPW/2015}

The first example is "Kata Pak Lurah rapatnya dimajukan"which translated into "The meeting time has been moved forward". Pak Lurah is the head of several villages in a district. Kata Pak Lurah itself means District Chief said that. The translator does not translate the phrase "kata Pak Lurah" because the sentence is enough to convey the meaning and intention of the utterance. In the target language, the decision of meeting in district office usually made by the district chief, thus without mentioning District Chief said that. Therefore by that reason, this strategy is used by the translator.

\section{SL: Habisanya, kamu dari tadi melamun ngeliatin jalanan doang!}

TL: Because, you're just watching the road!

Data 215/MPW/2015

The translator translated the sentence by deleting the word "melamun" that means "daydream" because in the context of story, you're just watching the road! has been able to convey the intention of utterance. Thus it shows that translation by omission used to translate the sentence to the target language.

\section{Discussion}

From the findings above the researchers found six translation strategies by Mona (1992) and the most used strategy is omission strategy with $24,9 \%$. To give brief discussion on what distinctions between this study and previous studies mentioned before, the researcher would explain some fundamental points of each study.

The first study is "The Translation Strategy of Slang Expression in Comic Entitled the Punisher" by Santika (2015). In the study, the researchers focused on analyzing slang translation strategies, the translation strategies of slang expression theory used by the researcher is by Butkuvienè \& Petrulione (2010). The result of the study indicated that the most used strategy is literal translation. The second study was done by Pradani (2017) discussed the translation analysis of humor in Webtoon "Si Juki: as a boarding house" by Faza Ibnu. The issue of the study is techniques in translating humor in Webtoon Si Juki. The translation technique theory used to categorize the data is by Molina \& Albir (2002). The result of the study indicated that there were 13 kinds of translation techniques found by the researcher and the mostly used translation technique is established equivalance with the total frequency of 19 data. And the last study was done by Issy Yuliasri entitled Translators' Censorship in English-Indonesian Translation of Donald Duck Comics (2018). In the study, the researcher focused on analyzing the translation technique as censorship of humor in Donald Duck comics. The translation technique strategy used to categorize the data is by Molina \& Albir (2002). The result of the study indicated that there were 17 translation techniques found by the researcher and the mostly used translation technique is discursive creation.

From the explanation above, there are clear distinctions between this study and the previous studies in which the previous studies did not discuss about the translation strategies in digital comic, specifically in the platform Webtoon. Besides, the analysis tool used by the researcher 
in this study and the previous studies was also different. In this case, the researcher used translation strategy by Mona Mona (1992), whereas, the first previous study used slang translation strategy by Butkuvienè \& Petrulionè (2010) and other two previous studies used translation technique by Molina \& Albir (2002). Thus, because of the different analysis tool and data source, the result of this study and previous studies also differ.

\section{Conclusion}

This paper is contribution to analysis of the translation strategies that occur in the Webtoon entitled "My PreWedding". The data shows that the translator just used six strategies used Mona (1922); Translation by a more general word 17 findings (6.5\%), Translation by cultural substitution 47 findings (18\%), Translation using a loan word 16 findings $(6.1 \%)$, Translation by paraphrase using a related word 53 findings $(20.3 \%)$, Translation by paraphrase using unrelated words 63 findings $(24.1 \%)$, Translation by omission 65 findings (24.9\%). The translator mostly used translation by omission and translation by loan word rarely used by the translator. Although omission strategy is the mostly used strategy, the use of omission does not intrude the story line because the common words which are mostly removed by the translator are complement words that can still persistently convey the meaning of utterance translated. From the result of this study, a good translator should use an appropriate strategy in translating an utterance according to its need in order to completely convey the meaning of each utterance without intruding on the story line.

\section{References}

Alqaryouti, M., \& Sadeq, A. (2016). Euphemism in the Translations of Surah Al Nisa'a in the Holy Quran. Journal of Literature, Languages and Linguistics, 3, 44-50.

Arabiyat, T. A. (2016). Theories and strategies of translation of political nuclear tests in the Jordanian Senate. Journal of Power, Politics \& Governance, 4, 17-46.

Butkuvienè, K., \& Petrulionè, L. (2010). Translation peculiarities of slanguage. Kalbu studijos, (16), 3943.

Creswell, J. W., \& Creswell, J. D. (2017). Research design: Qualitative, quantitative, and mixed methods approaches. Sage publications.

Ekasani, K. A., Yadnya, I. B. P., Artawa, K., \& Indrawati, N. L. K. M. (2018). Category Shifts in the Translation of Verb Phrases in English Cookbook into Indonesian. International Journal of Linguistics, Literature and Translation, 1(4), 290397.

Istiqomah, L., Erawati, M., \& Suparno, S. L. (2019). Discursive Creation Technique of English to Indonesian Subtitle in Harry Potter: The Chamber of
Secrets Movie. Lingual: Journal of Language and Culture, 7(1).

Molina, L., \& Albir, A. H. (2002). Translation techniques revisited: A dynamic and functionalist approach. Meta: Journal des Traducteurs/Meta: Translators' Journal, 47(4), 498-512.

Mona, B. (1992). In Other Words. A coursebook on translation. Journal of Women s Health.

Pelawi, B. Y. (2016). The Translation of Cultural Terms in the Novel "Rongeng Dukuh Paruk" by Ahmad Tohari. Jurnal Ilmu dan Budaya, 40(51), 5795-5808.

Pradani, S. (2017). Translation Analysis of Humor in Webtoon Si Juki: as a Boarding House (Doctoral Dissertation, Dian Nuswantoro University).

Riyanti, M. \& Setianto, D. (2018). The Digital Comic Development in Indonesia (A Case Study About The Story Of "Si Pitung"). International Journal of Research-Granthaalayah, 6(1), 107-117.

Saleh, N. J., \& Weda, S. (2018). Indonesian Poetry Translation: The Problem Within. Journal of English as an International Language, 13, 64-87.

Santika, D. (2015). The Translation Strategy of Slang Expression in Comic Entitled The Punisher. Buletin Al-Turas, 21(1), 127-144.

Yuliasri, I. (2017). Translators' Censorship in EnglishIndonesian Translation of Donald Duck Comics. Indonesian Journal of Applied Linguistics, 7(1), 105116.

Zanettin, F. (Ed.). (2015). Comics in translation. Routledge. 